\section{IJ§ER}

ISSN: 2149-5939
International Journal of Social Sciences and Education Research

Online, http://dergipark.gov.tr/ijsser

Volume: $2(2), 2016$

\title{
Same-sex marriage in US and European Court of Human Rights case law: A comparison ${ }^{1}$
}

\author{
Nazim Ziyadov ${ }^{2}$
}

Received Date: $23 / 10 / 2015$

Accepted Date: 07 / 01 / 2016

\begin{abstract}
Developments in human rights have led to the legal recognition of the right to marry as a fundamental right. However, recent social changes have caused reconsideration of just what that means. The traditional right entitles opposite sex couples to get married; this is now criticized using innovative legal analysis. Supporters of this new analysis claim that the right to marry shall be reconsidered to extend this right to same-sex couples. By way of comparison of legal reasoning of two courts, this paper tries to answer a question on potential changes in the case law of the European Court of Human Rights (ECtHR), based on the recent case law developments of the Supreme Court of the United States and ECtHR. In particular, the paper analyzes two critical cases. In the US, the landmark case is Obergefell et al. v. Hodges Director, Ohio Department of Health, 2015 where the US Supreme Court delivered a majority opinion establishing a rule for public authorities in different states to issue marriage licenses and certificates to the same-sex couple applicants. It was accompanied by strong dissenting opinions. This ruling leaded to controversy in states which do not recognize the marriage equality. In the ECtHR case law, the point of interest is Schalk and Kopf v. Austria, 2010 where the Court hesitated to recognize the right to same-sex marriage. Comparing the legal reasoning of these two courts applied in these cases, both describes the current status quo and highlights potential forthcoming changes in the position of the ECtHR.
\end{abstract}

Keywords: Same-sex Marriages; Sexual Discrimination; ECtHR; Right to Marry; Marriage Equality

\section{Introduction}

Freedom to marry has become a fundamental right. However, recent social changes throughout many countries have upended the traditional meaning of marriage as a union of a man and a woman. Supporters want to widen application of this right to same-sex couples. This legal problem has not only been on the agenda of the highest courts in different countries but also a focus of international judicial authorities. This paper analyzes this issue based on the recent case law developments of the US Supreme Court and European Court of Human Rights (ECtHR).

In particular, the paper analyzes two critical cases. In the United States, the landmark case is Obergefell et al. v. Hodges, Director, Ohio Department of Health, 2015. The US Supreme Court, with strong dissenting opinions, delivered a majority opinion establishing a rule that all public authorities must issue marriage licenses to same-sex applicants and recognize same-sex marriages. This ruling led to controversy in states that did not recognize same-sex marriages.

\footnotetext{
${ }^{1}$ This paper was presented at the International Conference on Social Sciences and Education Research organized on 29-31 October 2015 (Antalya, Turkey).

${ }^{2}$ Nazim Ziyadov, Ph.D. is an Assistant Professor at the Law School of Antalya International University (Antalya, Turkey). Any comments and remarks concerning this paper are highly appreciated and can be sent to nazim.ziyadov@antalya.edu.tr
} 
Ziyadov, N. (2016). Same-sex marriage in US and European Court of Human Rights case law: A comparison. International Journal of Social Sciences and Education Research, 2 (2), 387-401.

In ECtHR case law, the comparative case is Schalk and Kopf v. Austria, 2010. The ECtHR hesitated to recognize the right to marry for same-sex couples. It interpreted the margin of appreciation of the Council of Europe's members wider while considering the legal circumstances of the case. The final ruling of the ECtHR stated that no right to marry under the Convention for the Protection of Human Rights and Fundamental Freedoms (Convention) for same-sex couples exists. However, at the same time, the Court gave reasoning which supported the need for some kind of legal recognition of same-sex relationships under the category of 'family life'. The tendency in the ECtHR position to lean towards granting legal recognition of same-sex relationships culminated in another recent judgment of the ECtHR where it recognized an obligation of member states to provide same-sex couples with an alternative form of legal recognition (Oliari and Others v. Italy, 2015).

Today, the ECtHR does not require member states of the Council of Europe to recognize a right to marriage for same-sex couples. However, it is interesting to review its legal reasoning in light of the practice in the United States and to speculate whether any change in this position can be expected. This paper describes the legal reasoning used by two different courts in their respective judgments. And based on the comparison of structures of legal reasoning of the courts, it highlights, as far as it is practically possible, potential forthcoming changes in the position on the issue of same sex-marriages by the respective judiciaries.

\section{Scope of comparison}

The practices of the ECtHR and the US Supreme Court have been subject to comparison before. This comparison can be challenged with points relating to selection of elements for comparison. The US Supreme Court is the highest court in country (U.S. Const. art 3, sec 1). The ECtHR is a permanent judiciary organ established in accordance with the regional convention (Council of Europe, 1950) to ensure the observance of the engagements undertaken by the High Contracting Parties in the Convention and the Protocols thereto. The relationship between states in the US and the federal law is different from the one that exists between members of the Council of Europe and the Convention. In the US, there is constitution common to all states that has no counterpart for the members of the Council of Europe.

This constitutionalism is extremely important when it comes to the legal effect of the final judgments of these courts. The US Supreme Court applies its function as the watchdog of the Constitution and protects the supremacy of the Constitution while applying a uniform approach in application of federal law. The ECtHR, on the other hand, is concerned with the interpretation of the provisions of the Convention. It may be argued that both Courts are dependent on other branches of power or other international institutions when it comes to the enforcement of final judgments.

In the US, enforcement is carried out by the executive branch. In the case of the ECtHR, nonenforcement of the final judgment or judgments of the ECtHR is considered a breach of international law but not always of national law. When judgment is not enforced, the ECtHR may seek the application of measures by the Committee of Ministers of the Council of Europe. The potential mechanism for the enforcement of the ECtHR's final judgments is dependent on the political will of this Committee which may be linked to varying political circumstances existing at that time. It is possible to have other differences as well that may further challenge the grounds of comparing the two decisions. Such differences may involve the references to professional and educational 
Ziyadov, N. (2016). Same-sex marriage in US and European Court of Human Rights case law: A comparison. International Journal of Social Sciences and Education Research, 2 (2), 387-401.

backgrounds of judges, mechanisms applied for the appointment and dismissal of judges, decision-making techniques, writing, concurring and dissenting styles and practices, the history of existence of both courts, etc. Most importantly, there is a "societal" difference. There is an established society in the US with various views on marriage equality. In the territorial landscape of applicability of the ECtHR jurisdiction we have no ability to find a single society, i.e. a society of the Council of Europe peoples. Each member state has its own society with different views on marriage equality.

Having noted all these differences among many others, it is important to note that an objective here is not to focus on the analysis of such differences. Additionally, it is far beyond the scope of this paper to argue that there are many similarities in jurisdictions of two courts that may lead, at the end of the day, to similar outcomes. Both courts are trying to answer questions regarding recognition or rejection of same-sex marriage as a fundamental right. Therefore, the main objective of the comparison is to determine similarities or differences in making legal argumentation on the same subject matter exercised by different judges who are members of the highest court in a domestic jurisdiction and a regional judiciary body. Once the comparison is done, the possibility of making an argument regarding the potential direction of changes in law in the respective areas will be evaluated.

We begin with outlining the US case.

\section{US Practice: Obergefell et al. v. Hodges, Director, Ohio Department of Health, 2015}

The suit was brought by fourteen same-sex couples and two men whose same-sex partners were deceased. The petitioners were granted a writ of certiorari to the US Supreme Court with regards to judgment of the US Court of Appeals for the Sixth Circuit. The Appeals Court consolidated the cases and reversed the judgments of all six district courts, which initially decided in favor of the petitioners. The Appeals Court concluded that none of the involved states have an obligation to issue marriage licenses to same-sex couples and no recognition of same-sex marriages registered in the states that recognize this form of marriage can be required from the nonrecognizing states (Obergefell et al. v. Hodges, Director, Ohio Department of Health, 2015, page 2). The claim of the petitioners was based on alleged violation of the Fourteenth Amendment to the US Constitution (U.S. Const. amend. XIV) guaranteeing due process and equal protection under the law. In brief, the petitioners raised two issues. First, they were referring to the absence of recognizing the applicability of the right to marriage for same-sex couples. The second issue was the states which did not permit same-sex marriages would also not recognize those marriages that had been performed in other states.

Both the petitioners and the majority in their opinion focused on interpretation of the Fourteenth Amendment. This Amendment to the Constitution that was ratified in 1868 provides that, ' $[\mathrm{n}] \mathrm{o}$ state shall make or enforce any law which shall abridge the privileges or immunities of citizens of the United States; nor shall any state deprive any person of life, liberty, or property, without due process of law; nor deny to any person within its jurisdiction the equal protection of 
Ziyadov, N. (2016). Same-sex marriage in US and European Court of Human Rights case law: A comparison. International Journal of Social Sciences and Education Research, 2 (2), 387-401.

the laws'. ${ }^{1}$ The Court referred to its established case law while substantiating that the right to marry is protected under the Due Process Clause. ${ }^{2}$

The majority noted that ' $[\mathrm{t}]$ he identification and protection of fundamental rights is an enduring part of the judicial duty to interpret the Constitution' and the courts while performing this exercise, are obliged to give their reasoned judgments (Obergefell et al. v. Hodges, Director, Ohio Department of Health, 2015, page 10). Basically, it is up to the courts to state which right exists or comes into existence to render a judgment.

\section{Four principles and traditions}

The Court, after stating that the right to marry is a fundamental right which is protected under the Constitution, proceeded further with reasoning regarding a need for the recognition of the right to marry of same-sex couples. It focused on four principles and traditions to justify the need for recognition of right of same-sex couples to marry.

Individual Autonomy. The first premise to which the Court referred to is an area of the right to marry. The Court noted that this right falls under the most intimate areas of private lives of individuals (Obergefell et al. v. Hodges, Director, Ohio Department of Health, 2015, page 12). It stated that if we consider that family life shall be analyzed under the category of privacy then it would be illogical not to consider the decision-making process regarding establishment of the family as something which does not fall under the privacy. Therefore, a decision to be taken with respect to the establishment of marriage as an institution or to get same-sex marriage shall be considered to be part of privacy and cannot be limited by state law (Obergefell et al. v. Hodges, Director, Ohio Department of Health, 2015, page 13).

Two-Person Union. The second principle emphasized by the majority is the uniqueness of the marriage institution as a unity of two persons. This right is one of the oldest fundamental rights (and 'older than the Bill of Rights'), known to human society (Obergefell et al. v. Hodges, Director, Ohio Department of Health, 2015, page 13). Here the Court made a reference to Lawrence v. Texas, 2003 to justify its position regarding the second principle. In this case, the Court struck down a Texas law criminalizing same-sex relationships. It declared that the right to enjoyment of intimate association applicable to heterosexual couples shall also apply to same-sex couples. However, the Court noted that decriminalizing same-sex relationships does not suffice to achieve the exercise of full liberty by individuals. In order to achieve this, a further step must be taken to formalize the recognition in law of the two-person union of same-sex couples (Obergefell et al. v. Hodges, Director, Ohio Department of Health, 2015, page 14).

Childrearing, Procreation and Education. The Court underlined that the third basis making necessary protection of the family is the safeguarding of children and rights that relate to this,

\footnotetext{
${ }^{1}$ In fact, the Due Process provisions were introduced in the text of the US Constitution twice. In 1791 when the Bill of Rights was ratified, in the Fifth Amendment there was a requirement for the application of due process that intended the protection of life, liberty and property. However, this Clause of Due Process was applicable only with respect to the federal government. To extend the application of the Due Process Clause to the states, the Fourteenth Amendment was ratified.

${ }^{2}$ See, e.g.: Loving v. Virginia, 388 U.S. 1 (1967), Zablocki v. Redhail, 434 U.S. 374 (1978), Turner v. Safley, 482 U.S. 78 (1987), M. L. B. v. S. L. J., 519 U. S. 102 (1996); Cleveland Bd. of Ed. v. LaFleur, 414 U. S. 632 (1974); Skinner v. Oklahoma ex rel. Williamson, 316 U. S. 535 (1942); Meyer v. Nebraska, 262 U. S. 390 (1923).

The Supreme Court also referred to the cases where the question of same-sex marriages was raised. In particular, in Baker v. Nelson, 409 U.S. 810 that was delivered in 1972 it noted that a question on recognition of the right to samesex marriage is not a question of federal law and cannot be considered by the Court.
} 
Ziyadov, N. (2016). Same-sex marriage in US and European Court of Human Rights case law: A comparison. International Journal of Social Sciences and Education Research, 2 (2), 387-401.

such as 'childrearing, procreation, and education' (Obergefell et al. v. Hodges, Director, Ohio Department of Health, 2015, page 14). It noted that procreation has never been considered by the Court as a prerequisite for formation of the family. However, having a child and childrearing should be considered to be important elements that influence the scope of the application of the right to marry. It cited the Zablocki v. Redhail, 1978 case where it stated that establishment of home and bringing up children together with right to marry are a 'central part of the liberty protected by the Due Process Clause'. There is a tendency in the states to recognize right for samesex couples to adopt a child. And this matter, whether to allow same-sex marriages or not, should also be considered from this perspective. Same-sex couples, according to the Court, have already proved their ability to establish strong and stable relationships where they may provide the children with necessary family environment (Obergefell et al. v. Hodges, Director, Ohio Department of Health, 2015, page 15). Therefore, any state laws prohibiting same-sex marriages also limit the rights of children as well.

Marriage as a Keystone of Social Order. The Court made references to the $19^{\text {th }}$ Century work of Alexis de Tocqueville, 'Democracy in America' and to one of its own cases (Maynard $v$. Hill, 1888) decided in the same century as de Tocqueville's work was published to emphasize the importance of marriage as an institution in American society. Once the right to marry is recognized by the states it creates an area which offers further benefits to couples. These benefits may include 'taxation, inheritance and property rights; rules of intestate succession; spousal privilege in the law of evidence; hospital access; medical decision-making authority; adoption rights; the rights and benefits of survivors; birth and death certificates; professional ethic rules; campaign finance restrictions; workers' compensation benefits; health insurance; and child custody, support, and visitation rules' (Obergefell et al. v. Hodges, Director, Ohio Department of Health, 2015, page 17). The Court held that it is unreasonable to apply discriminatory rules with respect to same-sex couples whose interests potentially are damaged due to refusal to recognize samesex marriages. According to the Court, their damage was not only material.

The Due Process Clause of the Constitution was not the only constitutional requirement used by the majority to justify its position. In addition, it used Equal Protection Clause. It claimed that right to marry, if it is extended to same-sex couples, does not infringe the beliefs of supporters of traditional concept of marriage. On the contrary, the absence of recognition of same-sex marriages in different states causes differential treatment of a particular group that requires justification. No justification provided by the respondents was considered sufficient. The issue at hand is not about development of something new in law. According to the Court, when it states that same-sex couples shall be allowed to obtain marriage certificates, it does not create a new right but confirms the existence of the respective right, which shall be guaranteed under both Due Process and Equal Protection Clauses (Obergefell et al. v. Hodges, Director, Ohio Department of Health, 2015, page $18,22)$.

Considering that the issue under analysis cannot be handled as an issue unrelated to these two Constitutional requirements, the majority explicitly overruled Baker v. Nelson, 1972, which had rejected hearing a question on the right of same-sex couples to marry and declared it as purely matter of jurisdiction for the states', with no link to federal law. The US Supreme Court went even further and stated that the right at issue is so fundamental that it cannot be decided upon by popular vote. And it is the courts who must protect and enforce this fundamental right. It even 
Ziyadov, N. (2016). Same-sex marriage in US and European Court of Human Rights case law: A comparison. International Journal of Social Sciences and Education Research, 2 (2), 387-401.

touched upon another case. It noted that in the Bowers v. Hardwick, 1986 case, ${ }^{1}$ the Court was wrong from the beginning. In this case, the Court had upheld the constitutionality of a Georgia sodomy law that criminalized oral and anal sex between homosexuals even between consenting adults. The Court's position on this 'wrong' was that even if Bowers v. Hardwick judgment was overturned by another case later (Lawrence v. Texas, 2003) in 2003, its existence did not overshadow the fundamental rights of individuals practicing homosexuality. In other words, the Court noted that consideration of the matters in ways that differ from current majority's position could not be regarded as existence of doubt about the liberty protecting same-sex marriages.

Consequently, the Court concluded that the states have no constitutional right to limit the right of same-sex couples to get married. All states must issue marriage licenses to same-sex couples. Further, none of the states have the right to reject the recognition of same-sex marriages created in other states.

The position of the majority raised very strong dissent by the Court's minority. ${ }^{3}$ Justice Scalia referred to the majority's opinion as a 'threat to American democracy' and a 'judicial Putsch' (Justice Scalia's Dissenting Opinion, pp 1 and 6). The position of the dissenting opinions is unified with respect to the main general argument. They argue that it is artificial to create a right which is not recognized by the Constitution. In other words, the question is not whether same-sex couples shall be provided with the right to marry or not, but who should decide on this matter, the federal government or the states. The dissenting justices stated that the right to marry and the applicability of its scope cannot be regarded as something regulated by the Federal Constitution. The Founders deliberately granted to the states the competence to decide on these matters. A delivery of a judgment obligating states to issue marriage licenses to same-sex couple applicants, violates the idea of Constitutionalism. This matter shall properly be decided by citizens of the states by legislating in their respective legislatures or by referenda or by any other democratic tools the states may consider suitable for this purpose. Unelected and unaccountable judges shall not decide on behalf of the states. To do so, the dissenters argued, may create very a dangerous historical precedent. The political debates and processes that led, at the time of adoption of the judgment by the Court, to the recognition of same-sex marriages by voters or legislators in eleven states and District of Columbia should continue as the Court itself is not a legislator (Chief Justice Roberts's Dissenting Opinion, pp 1-2).

Now, we turn to how the issue was handled by the ECtHR.

\section{ECtHR Practice: Schalk and Kopf v. Austria, 2010}

As is the case with the US, the ECtHR has pre-existing rulings regarding various aspects of homosexuality. The ECtHR has decided many cases in the area of gender identity and sexual

\footnotetext{
${ }^{1}$ The Bowers v. Hardwick, 1986 case where the Court stated that there was no constitutional right to sexual privacy, as Obergefell et al. v. Hodges, Director, Ohio Department of Health, 2015 was decided by a 5 to 4 majority.

${ }^{2}$ The judgment in Lawrence v. Texas, 2003 was also delivered by 5 to 4 majority. It overturned the previous Bowers $v$. Hardwick, 1986 judgment and declared all state laws criminalizing sodomy to be unconstitutional.

${ }^{3}$ Each of the justices who were in the minority delivered separate dissenting opinions. Chief Justice Roberts's dissenting opinion was joined by Justices Scalia and Thomas; Justice Scalia's dissenting opinion was joined by Justice Thomas; Justice Thomas's dissenting opinion was joined by Justice Scalia; and Justice Alito's dissenting opinion was joined by Justices Scalia and Thomas.
} 
Ziyadov, N. (2016). Same-sex marriage in US and European Court of Human Rights case law: A comparison. International Journal of Social Sciences and Education Research, 2 (2), 387-401.

orientation. ${ }^{1}$ Different provisions of the Convention were referred to by applicants who started or tried to start proceedings before the ECtHR depending on the circumstances at issue. The range of these provisions under the Convention varied from the right to privacy to the right to a fair trial. An important proportion of the cases heard by the ECtHR relates to Articles 8 and 12 of the Convention that respectively guarantee respect for private and family life and the right to marry. An additional provision of the Convention, Article 14 prohibiting discrimination, is often used by applicants in conjunction with other provisions of the Convention.

The case of Schalk and Kopf v. Austria was decided in June 2010 by the First Section of the ECtHR. The applicants were two male nationals of Austria who applied to the ECtHR in 2004. They raised two issues regarding alleged violations of their rights under the Convention. First, the applicants argued that 'they were denied the possibility to marry'. Secondly they had no chance to recognize their relationships in any other form under domestic law (Schalk and Kopf v. Austria, 2010, para 3). Here, the legal strategies of the applicants were different from that of their American counterparts. The Austrian applicants stated that in addition to formal right to marriage of same-sex couples there is another possibility for a member state to consider, i.e. to recognize the civil partnerships or unions of same-sex couples.

According to Austrian law, in particular the Austrian Civil Code, marriage was considered as an institution that may be initiated between two persons of the opposite sex. The case law of this country was developed in such a way that any alleged right to marriage between same-sex couples was declared null and void (Schalk and Kopf v. Austria, 2010, para 9). The Constitutional Court of Austria, that heard the case as a court of last resort within the country confirmed the conclusions of the lower courts. It noted that such conclusions were in line with the established case law of the country.

Austria's Constitutional Court, however, did not limit its analysis of the issue of the applicability of the marriage contract to same-sex couples under domestic law. It extended its analysis to a review of equality provisions provided in the Constitution in light of the Convention and established case law. It concluded that the equality right, as such, which is guaranteed by the Austrian Federal Constitution does not require the state to grant same-sex couples the right to marry. ${ }^{2}$ It went further, analyzing ECtHR case law and came to the conclusion that ECtHR case law similarly does not put a legal obligation on member states to guarantee the right to marry to same-sex couples. Based on the reasoning of the ECtHR in Cossey v. the United Kingdom, $1990^{3}$ and Christine Goodwin v. the United Kingdom [GC], 2002 ${ }^{4}$ it indicated that the traditional marriage concept

\footnotetext{
${ }^{1}$ For summaries of the landmark cases in these areas see: Factsheet of the ECtHR on Sexual Orientation Issues, July 2015, Factsheet of the ECtHR on Gender Identity Issues, May 2015 and Factsheet of the ECtHR on Homosexuality: Criminal Aspects, June 2014.

${ }^{2}$ Sections 1 and 2 of Article 7 of the Austrian Federal Constitution offer a general clause that prohibits discrimination based on sex and obligates the central government, federal subjects and municipalities to take necessary measures to ensure de facto equality.

${ }^{3}$ This case was decided by a final judgment of the ECtHR on 27 September 1990. The ECtHR found that there was no violation of Article 8 (the right to respect for private and family life) because gender reassignment surgery does not lead to entitlement to all biological characteristics of the opposite sex. Further, it found no violation of Article 12 (the right to marry and found a family) because the traditional concept of marriage provides sufficient reason to believe that opposite-sex marriage institution shall be preserved without putting a burden on the member states to change their domestic laws (Cossey v. the United Kingdom, 1990, paras 40 and 46).

${ }^{4}$ The case was decided on 11 July 2002 by the Grand Chamber of the ECtHR where it found violations of Articles 8 and 12. According to the ECtHR position, denying acceptance of gender changes of transsexuals violates their rights under the Convention. In particular, the member states shall provide a mechanism that would allow them to exercise their right to marry after the change of their genders (Christine Goodwin v. the United Kingdom [GC], 2002, para 103).
} 
Ziyadov, N. (2016). Same-sex marriage in US and European Court of Human Rights case law: A comparison. International Journal of Social Sciences and Education Research, 2 (2), 387-401.

being between a man and a woman was justified and the ECtHR did not put any extra burden on member states to amend their laws to broaden the definition. In other words, recognition of a right to marry of transsexuals after the gender-change surgery in Christine Goodwin v. the United Kingdom $[G C], 2002$ does not mean that the competence of the member states to determine the substance of the marriage is altered. The approach of the Constitutional Court was that deciding whether to widen the traditional marriage concept by including same-sex marriages under the umbrella of this institution was purely a matter of policy. Further, it emphasized that it did not have to interfere in the activities of legislature by advising it how to change the existing legislation (Schalk and Kopf v. Austria, 2010, para 13).

Interestingly, the domestic law of Austria changed after the filing of application to the ECtHR by the applicants in Schalk and Kopf v. Austria, 2010 case. The legislature adopted a new statute (Registered Partnership Act) that came into force on 1 January 2010 (Schalk and Kopf v. Austria, 2010, para 17). This Act granted legal recognition to same-sex partners intending to establish registered partnerships. ${ }^{1}$ Although there were many similarities between the traditional oppositesex marriage concept and the newly-established registered partnerships, some status differences remained under this Act. $^{2}$

The applicants' claims regarding the denial of the right to marry and absence of recognition under Austrian law of the same-sex relationships in Schalk and Kopf v. Austria, 2010 were analyzed in light of Article 12 of the Convention providing right to marry and Article 14 of the Convention prohibiting discrimination taken in conjunction with Article 8 guaranteeing the right to private and family life.

\section{Right to Marry}

Article 12 of the Convention provides that men and women of marriageable age have the right to marry and to found a family in accordance with the particular laws governing marriage within each country. The text of this provision gives member states the discretion to determine the applicable rules. However, while evaluating the margin of discretion of the member states the ECtHR, as it is usual in its case law, tends to create extra requirements regarding those limits. The ECtHR demands that states not damage the essence of the right (Schalk and Kopf v. Austria, 2010, para 49). The importance of the judgment of Schalk and Kopf v. Austria is that in this case the ECtHR attempted to address the question in substance. Although the case law of the ECtHR had been rich with cases that involved claims of sexual minorities, it never tried to directly answer the question of whether same-sex couples had a right to get married under the Convention.

Initially, in its case law, the ECtHR was hesitant to recognize a right of transsexuals to get married based on their assigned gender after undergoing an operation. It was focused on the importance of the biological criterion for evaluating the right to marry provided in the Convention

\footnotetext{
${ }^{1}$ This Act provided same-sex couples with a regime similar to one that existed under traditional marriage guaranteed by the Austrian Civil Code. Similarities included such matters as living together, sharing a common home, providing mutual assistance, and representing the other partner in legal transactions. Dissolution of registered partnerships and marriages was similar too. Additionally, obligations applicable to traditional marriages were also applicable to registered partners in the registered partnerships (Schalk and Kopf v. Austria, 2010, paras 20-22).

${ }^{2}$ The ECtHR was referring to three main differences between them. First, different public authorities were responsible for the registration of marriages and partnerships. Secondly, the expression of 'family name' was used only with respect to married couples while registered partners could only be bound by a 'common name'. Last but not least, parental rights of registered partners were limited as they were not allowed to adopt a child or stepchild (Schalk and Kopf $v$. Austria, 2010, para 23).
} 
Ziyadov, N. (2016). Same-sex marriage in US and European Court of Human Rights case law: A comparison. International Journal of Social Sciences and Education Research, 2 (2), 387-401.

(Sheffield and Horsham v. the United Kingdom, 1998; Cossey v. the United Kingdom, 1990; and Rees v. the United Kingdom, 1986). However, this focus on biology changed in later case law. Specifically, in Christine Goodwin v. the United Kingdom [GC], 2002 the ECtHR declared that after the operation on transsexuals leading to the establishment of an assigned gender, the member states were not entitled to refer to the margin of appreciation and deny applicability of the right to marriage to such persons. The biological criterion could not be considered sufficient to apply the margin of appreciation by member states in order to reject the right to marry under the Convention. The broad interpretation of Article 12 with respect to the rights of transsexuals willing to enter marriage after an operation for assigned gender was not used with respect to existing marriages. In two cases, applicants were complaining that their marriage could be terminated if the legal recognition procedure with respect to gender was implemented. ${ }^{1}$ In other words, the applicants were initially opposite-sex couples where males underwent a gender change (male-tofemale) operation. The ECtHR stated that their request to protect their marriage rights was not supported within the traditional concept of marriage as same-sex marriages were not allowed. Even if the concept of marriage was extended for same-sex couples by some of the member states, it reflects only the values of the societies in their respective countries. According to the ECtHR, these values were not representing the interpretation of a respective right under the Convention, i.e., it was up to the member states to solve the matter regarding change of gender in existing marriages (Schalk and Kopf v. Austria, 2010, para 53).

The ECtHR first analyzed the matter in the light of literal interpretation. It specifically referred to Article 9 of the European Charter on Human Rights of the European Union (European Union, 2010) where the Charter guarantees right to marry and the right to found a family in accordance with the national laws governing exercise of these rights. The Charter, according to the ECtHR, considered recent changes in the traditional concept of marriage that came into existence in legislations of the EU member states. Therefore, it deliberately refrained from making reference to "men" and "women". The ECtHR noted that even if the Charter omitted specific references to gender in the text of Article 9, it created some room for member states to act with discretionary power in accordance with their views on social changes occurring in their respective societies. As the ECtHR noted further, even in the Commentary to the Charter refraining from making reference to gender was once more stressed directly. ${ }^{2}$ The Commentary explicitly states that member states have no legal obligation in practice to unify their marriage laws in order to allow same-sex marriages.

Based on the ECtHR's literal interpretation of the text of the Convention, in connection with other provisions, it concluded that the drafters of the Convention deliberately meant that the right to marry was specifically applicable to opposite-sex couples (Schalk and Kopf v. Austria, 2010,

\footnotetext{
${ }^{1}$ Parry v. the United Kingdom (dec.), no. 42971/05 and R. and F. v. the United Kingdom (dec.), no. 35748/05. Both cases were declared manifestly ill-founded and rejected by the Fourth Section in grounds of inadmissibility.

${ }^{2}$ The Commentary of the Charter of Fundamental Rights of the European Union, June 2006 on page 102 provides as follows:

In order to take into account the diversity of domestic regulations on marriage, Article 9 of the Charter refers to domestic legislation. As it appears from its formulation, the provision is broader in its scope than the corresponding articles in other international instruments. Since there is no explicit reference to 'men and women' as the case is in other human rights instruments, it may be argued that there is no obstacle to recognize same-sex relationships in the context of marriage. There is, however, no explicit requirement that domestic laws should facilitate such marriages. International courts and committees have so far hesitated to extend the application of the right to marry to same-sex couples.'
} 
Ziyadov, N. (2016). Same-sex marriage in US and European Court of Human Rights case law: A comparison. International Journal of Social Sciences and Education Research, 2 (2), 387-401.

para 55). Having said that the textual (literal) interpretation was not used to justify main arguments of the applicants, it analyzed the possibility of interpreting the Convention in the light of present-day conditions as a living instrument. Although it accepted that the concept of marriage might have undergone major changes since the era of the 1950s (the era when the ECtHR was initially established), it rejected arguments requiring that the Convention be interpreted in light of present-day conditions. Using such an interpretation was impossible because of the absence of a European consensus on the issue (Schalk and Kopf v. Austria, 2010, para 58).

After noting that the interpretation of the Convention in light of present-day conditions did not allow for accepting Article 12 as a provision that could be used to require member states to recognize the right of same-sex couples to marry, the ECtHR stated the importance of the fact regarding the change in attitudes in some European countries. By reference to Article 9 of the Charter of Fundamental Rights of the European Union, it noted that the right to marry is enshrined in the Convention. Although this does not provide an obligation for member states to recognize same-sex marriages, it provides a possibility for the member states to interpret it in as a provision that allows such marriages and supports respective domestic laws (Schalk and Kopf v. Austria, 2010, para 61). In evaluating the position of the member states with respect to the question this portion of the ECtHR judgment is important:

In that connection, the Court observes that marriage has deep-rooted social and cultural connotations which may differ largely from one society to another. The Court reiterates that it must not rush to substitute its own judgment in place of that of the national authorities, who are best placed to assess and respond to the needs of society (Schalk and Kopf v. Austria, 2010, para 62, References in original omitted).

This statement alone shows how cautious the ECtHR is when it evaluates the potential effect of its judgments on sensitive areas. It accents on social and cultural connotations of different notions that shall be considered by it. Further, it shows its hesitance to protect a particular position, even when there are different interpretation methods that could firmly ground a given position. This is due to the threat that judgments might go unenforced. In the last sentence of the quoted paragraph, the ECtHR drives home an analogy which is often used by different judiciary authorities. The intention to leave a decision in the hands of different national authorities is very similar to that of dissenting judges in the US who advocated leaving the question of same sex marriages as a matter for the state legislatures (or the people in referenda) to decide.

\section{Alleged discrimination leading to the violation of the right to private and family life}

Another aspect that was assessed by the ECtHR is a link between the right to private and family life and the relationships between same-sex couples. This question, in fact, has been considered by the ECtHR in previous cases many times. ${ }^{1}$ The approach of the ECtHR was that applicants could claim their rights under two articles of the Convention as Article 14 of the Convention can be used in conjunction with other provisions of the Convention, including Article 8. There is an interesting aspect to this: the ECtHR's consideration of two separate matters. It emphasized that

\footnotetext{
${ }^{1}$ In some of the cases, for instance, in cases on the prohibition of homosexual acts under criminal law provisions of the different member states, the rights of homosexuals were considered solely in the light of Article 8 (Dudgeon v. the United Kingdom, 1981; Norris v. Ireland, 1988; and Modinos v. Cyprus, 1993). In other cases, the ECtHR heard the applications in the light of two articles of the Convention, i.e. Articles 8 and 14 taken in conjunction $(L$. and $V$. v. Austria, 2003; Salgueiro da Silva Mouta v. Portugal, 2000; Fretté v. France, 2000 and E.B. v. France [GC], 2008; Karner v. Austria, 2003). 
Ziyadov, N. (2016). Same-sex marriage in US and European Court of Human Rights case law: A comparison. International Journal of Social Sciences and Education Research, 2 (2), 387-401.

there is no need to analyze the question of whether same-sex couples' relationships are considered to be part of private life or not. The ECtHR noted that this matter was not under dispute anymore and relationships of same-sex couples must be considered as an element of private life that can be protected under the Convention. However, it noted that another question to be answered was whether such relationships fell under the label of family life (Schalk and Kopf v. Austria, 2010, para 90). Having raised this question, it referred to its own case law where this matter had already been analyzed from other perspectives. In other words, in general, the ECtHR stated that it did not restrict the interpretation of 'family life' to be something applicable only to de jure relationships under wedlock. However, the choice to recognize stable relationships between same-sex couples as part of family life had not been previously possible as there was little common ground between the European countries on the issue (Schalk and Kopf v. Austria, 2010, para 92). The absence of this widespread common ground created an area for the application of the margin of appreciation where they could independently determine the limits of interpretation. ${ }^{1}$ However, the ECtHR emphasized the importance of changes that had taken place in Europe in general and the European Union in particular. Such changes of national laws in some of the European countries made it possible for the ECtHR to reconsider the interpretation of the Convention. And it considered that it would be artificial to preserve the old interpretation. As a result, it noted that 'the relationship of the applicants, a cohabiting same-sex couples living in a stable de facto partnership, falls within the notion of "family life", just as the relationship of a different-sex couple in the same situation would' (Schalk and Kopf v. Austria, 2010, para 94).

Once the ECtHR recognized the need to change its approach regarding a broad interpretation of family life, it proceeded with an analysis of the existence of any kind of discrimination against same-sex couples. The ECtHR stated that any kind of difference in treatment by member states of the Council of Europe must have a reasonable justification and proper objective. Treatment cannot be considered justifiable if it fails to pursue a legitimate aim or if the means used and the aim are not proportionate (Schalk and Kopf v. Austria, 2010, para 96). The general rules that have been developed with respect to prohibition of discrimination are also applicable to difference in treatment based on sex. In each case, the margin of appreciation of member states was dependent upon specific circumstances (Schalk and Kopf v. Austria, 2010, para 98).

It is worth noting that the Court raised a question regarding the similarity of conditions of same-sex and opposite-sex couples even if, as it noted, this matter was not explicitly referred to by the parties. It noted that relationship in same-sex couples shall be considered stable and a committed relationship as is the case with the opposite-sex couple relationships and '... they are in a relevantly similar situation ...' (Schalk and Kopf v. Austria, 2010, para 99).

The applicants raised two issues that allegedly indicated that they had been discriminated against. A failure by Austria to allow same-sex couples entering marriage led to discrimination. In addition to the absence of a right to marry under Austrian law, same-sex couples were not provided with a right to formalize their relationships using an alternative method of recognition.

\footnotetext{
${ }^{1}$ The ECtHR was mainly referring to the case of Mata Estevez v. Spain (dec.) no. 56501/00, ECtHR 2001-VI where it showed that there is little shared common ground between European States with respect to recognizing same-sex relationships under the label of family life. An applicant in this case was a man in a homosexual couple which cohabited together for more than ten years. The de facto partner of the applicant died in a road accident. The applicant failed in his efforts to obtain the social security benefits of his deceased partner. Local courts rejected his claim to enjoy his partner's social security benefits because, under Spanish law, same-sex marriages were not recognized. The ECtHR in its turn declared the application by Estevez inadmissible.
} 
Ziyadov, N. (2016). Same-sex marriage in US and European Court of Human Rights case law: A comparison. International Journal of Social Sciences and Education Research, 2 (2), 387-401.

However, while evaluating the issue of discrimination, the logic of the ECtHR was straightforward and simple. It indicated that it had previously been noted that the Convention does not require member states of the Council of Europe to grant same-sex couples the right to marry under Article 12. Therefore, if the specific provision of the Convention does not require granting such a right, one may not come to the conclusion that the right may be derived from other less specific norms of the Convention. In other words, it could not be considered that same-sex applicants are discriminated against simply because their right to marry under Austrian law is absent.

Amendments made to Austrian law in 2010, after the date of the application and before the date of the hearings, changed the status of the complaint. Austria introduced legislation that recognized same-sex relationships as a separate form of common habitation. That is why it was necessary for the ECtHR to answer the question of whether Austria was in breach of its obligations under the Convention prior to the date of the amendments (Schalk and Kopf v. Austria, 2010, para 104). The ECtHR held that 'there is not yet a majority of States providing for legal recognition of same-sex couples. The area in question must therefore still be regarded as one of evolving rights with no established consensus, where States must also enjoy a margin of appreciation in the timing of the introduction of legislative changes' (Schalk and Kopf v. Austria, 2010, para 105).

\section{Other claims}

In addition to the references to Articles 8, 12 and 14, the applicants in the Schalk and Kopf $v$. Austria, 2010 case also made reference to another provision of the Convention. In particular, they mentioned that the absence of recognition of same-sex marriages in Austrian laws and absence of any alternative legal mechanisms recognizing same-sex relationships violates their rights provided under Article 1 of Protocol 1 of the Convention (Protection of Property). ${ }^{1}$ Their idea standing behind this claim was to build a link between discriminatory treatment by the state and its casual result in the form of financial disadvantages. However, this claim was dismissed without consideration by the ECtHR. The position of the ECtHR was due to the absence of proper justification for this claim made by applicants.

\section{Dissenting opinion}

The position of the ECtHR on a question regarding the right to marry was unanimous. That is, it delivered a final judgment that expressed the views of all seven members of the First Section that declared the absence of any violation of Article 12 of the Convention. It concluded by unanimity that Austria was not under obligation to recognize the same-sex marriages in its domestic law. However, no unanimity existed in answering another question that related to the alleged violation of Article 14 taken in conjunction with Article 8. Three members of the First Section (Judges Rozakis, Spielmann and Jebens) dissented with a separate opinion. The dissenting judges considered the approach of the majority to reconsider the issue regarding the claims of same-sex couples to rely on family life to be a progressive one. However, they noted that once stable relationships of same-sex couples are recognized as part of family life then any absence of legal

\footnotetext{
${ }^{1}$ According to this Article,

Every natural or legal person is entitled to the peaceful enjoyment of his possessions. No one shall be deprived of his possessions except in the public interest and subject to the conditions provided for by law and by the general principles of international law.

The preceding provisions shall not, however, in any way impair the right of a State to enforce such laws as it deems necessary to control the use of property in accordance with the general interest or to secure the payment of taxes or other contributions or penalties.
} 
Ziyadov, N. (2016). Same-sex marriage in US and European Court of Human Rights case law: A comparison. International Journal of Social Sciences and Education Research, 2 (2), 387-401.

recognition of such relationships must be justified by the member states (Schalk and Kopf v. Austria, 2010, Joint Dissenting Opinion of Judges Rozakis, Spielmann and Jebens, page 27, para 8). The basic reference to the right to enjoyment of margin of appreciation on this matter is not sufficient for any state. In the view of the judges in the minority, Austria was in breach of its obligations under Article 14 taken in conjunction with Article 8. In violation, that is until the introduction of the legislative amendments that recognized same-sex relationship as separate form of inhabitation.

\section{Conclusion}

As we have seen, the mechanisms of the Courts are entirely different, limiting the value of comparison especially when trying to make predictions about future rulings. Despite this, there is a striking similarity: both Courts are responding to shifting realities and the social change in their societies. And in both Courts, public opinion matters and affects how the courts rule. In the case of the US, American approval of same-sex marriage had risen dramatically in only a few years. The ruling by the court in many ways reflected that change. The ECtHR is entirely different in that its opinions are constrained by a much more powerful desire not to disrupt the choices of the member nations. Yet even in this instance we see the same dynamic: shifts in popular views are gathering steam - just like in the US. And, more importantly for our purposes, the ECtHR is beholden to keep pace with those changes.

Although based on the review of these two cases it is hard to come to any absolute conclusions on the possible directions of case law developments in the US Supreme Court and ECtHR, it is still possible to find out the starting points that have been used by these two courts while deciding the same matter from different perspectives. The US Supreme Court had played an important role in the formation of constitutional principles. It also has contributed greatly to the development of human rights law doctrine of the country. However, its judgments were not always far from controversy. Sometimes, it took a less liberal position with respect to pending social issues and was very cautious. And its practice is familiar with changing precedents. The judgment in Obergefell et al. v. Hodges, Director, Ohio Department of Health, 2015 was delivered by a deeply divided 5-4 majority. However, the probability for change in the Supreme Court's position is small, given the direction of the Court's development.

The picture is different on the European continent where we see a different center of argumentation. The US Supreme Court developed a more individual-centered approach where the ECtHR developed the sovereign-centered approach. Although the US Supreme Court refers to a cautious approach, which it tries to use in the process of delivering judgments from the style of argumentation and the structure of building the case law, it is clear that caution is used in a more constant way by the ECtHR. This is especially a case when it comes to judgments that may lead to serious changes in the legal system of the member states of the Council of Europe. While deciding whether a particular member state violates the Convention due to the absence of legislation allowing same-sex marriages, it can cause very serious ramifications. Requiring such a change may require a change in the whole system of family of law of the respective country with potential implications for other member states. This judgment has a 'group effect' that is different from other daily judgments that may have an 'individual effect'.

Judgments, such as one concerning the violation of the right to a fair trial where the accused was not brought before the court in a timely manner despite there being a provision in the law, 
Ziyadov, N. (2016). Same-sex marriage in US and European Court of Human Rights case law: A comparison. International Journal of Social Sciences and Education Research, 2 (2), 387-401.

have only an individual effect. They tend to change the legal status of one person or small group. The potential group effect of the ECtHR judgment is even higher when one considers that there is no established European consensus between member states.

Considering that the ECtHR has a tendency to refer to the doctrine of margin of appreciation when there is a group effect, we may expect that the position of the ECtHR would only change where there is a well-established European consensus on this issue. In other words, even the change in the structure of the ECtHR, i.e. appointment of new judges, is unlikely to affect its position on this matter. The main impetus would be changes in legislation of member states which in own turn may facilitate the sovereign-centered court to act. Here, we have a dilemma regarding the legal recognition. Although the ECtHR answered both questions on legal recognition negatively and it stated that Austria is not under an obligation to recognize same-sex marriages and it was not under an obligation to introduce separate legislation where it would recognize the civil partnership institution established with respect to same-sex couples, the court's position has already been changed. In Oliari and Others $v$. Italy, 2015, only five years after the date of final judgment in Schalk and Kopf v. Austria, 2010, it found a violation of provisions of the Convention. In this case, the ECtHR referred to an emerging European consensus that recognizes the relationships of same-sex couples. ${ }^{1}$ Having noted that twenty-four out of the forty-seven members of the Council of Europe 'have already enacted legislation permitting same-sex couples to have their relationship recognized as a legal marriage or as a form of civil union or registered partnership' (Oliari and Others v. Italy, 2015, para 55) the ECtHR felt confident to pressure democratic processes that were taking place in Italy:

Turning back to the situation in Italy, the Court observes that while the Government is usually better placed to assess community interests, in the present case the Italian legislature seems not to have attached particular importance to the indications set out by the national community, including the general Italian population and the highest judicial authorities in Italy (Oliari and Others v. Italy, 2015, para 179).

In other words, the ECtHR reconsidered the same matter from a different perspective. It noted that in Italy the same-sex couples have no ability to get married. And similarly to applicants in Schalk and Kopf v. Austria, 2010 at the date of their application to the ECtHR, the applicants in Oliari and Others v. Italy, 2015 have no opportunity to get legal recognition of their relationships as partnerships or civil unions. However, considering that judicial authorities in Italy were tending to lean towards recognition of same-sex relationships under legal partnership, and emerging changes in legislatures of different European countries, the ECtHR decided to declare Italy to be in violation of provisions of the Convention.

This position of the ECtHR, which is rooted in Schalk and Kopf v. Austria, 2010, allows it to take a break on this matter. It is highly probable that in coming cases the ECtHR would tend to recognize a violation of Article 8 and Article 8 in conjunction with Article 14 when a question regarding the recognition of same-sex relationships is raised as it did in Oliari and Others v. Italy, 2015. However, it would hesitate, at least until the time when the vast majority of the member

\footnotetext{
${ }^{1}$ The ECtHR noted that same-sex marriages are recognized in eleven of the Council of Europe countries. In eighteen member states, an alternative mechanism to recognize the same-sex relationships is offered. In addition, there were states in which discussion of different bills concerning this matter were on the political agenda (Oliari and Others $v$. Italy, 2015, paras 53-54).
} 
Ziyadov, N. (2016). Same-sex marriage in US and European Court of Human Rights case law: A comparison. International Journal of Social Sciences and Education Research, 2 (2), 387-401.

states of the Council of Europe recognized the same-sex marriages in their domestic laws, to declare a violation of Article 12 of the Convention.

\section{References}

Baker v. Nelson 409 U.S. 810 (1972).

Bowers v. Hardwick, 478 U.S. 186 (1986).

Christine Goodwin v. the United Kingdom [GC] (European Court of Human Rights 2002).

Cossey v. the United Kingdom (European Court of Human Rights 1990).

Council of Europe. (1950). Convention for the Protection of Human Rights and Fundamental Freedoms

European Union (2010). Charter of Fundamental Rights of the European Union. Official Journal of the European Union C83 (Vol. 53, p. 380). Brussels: European Union.

Factsheet of the ECtHR on Gender Identity Issues, May 2015.

Factsheet of the ECtHR on Homosexuality: Criminal Aspects, June 2014.

Factsheet of the ECtHR on Sexual Orientation Issues, July 2015.

James Obergefell, et al., Petitioners v. Richard Hodges, Director, Ohio Department of Health, et al.; Valeria Tanco, et al., Petitioners v. Bill Haslam, Governor of Tennessee, et al.; April DeBoer, et al., Petitioners v. Rick Snyder, Governor of Michigan, et al.; and Gregory Bourke, et al., Petitioners v. Steve Beshear, Governor of Kentucky 576 U.S. (2015).

Lawrence v. Texas, 539 U.S. 558 (2003).

Maynard v. Hill, 125 U.S. 190 (1888).

Oliari and Others v. Italy (European Court of Human Rights 2015).

Rees v. the United Kingdom (European Court of Human Rights 1986).

Schalk and Kopf v. Austria (European Court of Human Rights 2010).

Sheffield and Horsham v. the United Kingdom (European Court of Human Rights 1998).

U.S. Constitution.

Zablocki v. Redhail, 434 U.S. 374, 384 (1978). 